\title{
NOTES
}

\section{A HOUSE FINCH'S SUCCESSFUL USE OF A BARN SWALLOW NEST}

LEO C. GASKINS, Duke University Marine Lab, 135 Duke Marine Lab Rd, Beaufort, North Carolina 28516; leo.gaskins@duke.edu

The ability to adapt to and thrive in human-dominated landscapes has allowed the House Finch (Haemorhous mexicanus) to become one of the most widely distributed songbirds in North America and has allowed the Barn Swallow (Hirundo rustica) to become the widest-ranging swallow in the world (Alsop 2006). As a result of adapting to nest on artificial structures and the House Finch's introduction to the east coast of the United States (Aldrich and Weske 1978), these species' overlap increased greatly. Both species inhabit disturbed areas (Badyaev et al. 2012) and construct cup-shaped nests, but House Finches use twigs, grasses, leaves, and a lining of finer materials, while Barn Swallows use dried mud and grass with a lining of feathers or hair (Alsop 2006). As the chicks grow, a characteristic ring of feces forms around the edge of House Finch nests (Evenden 1957), but Barn Swallow chicks defecate over the edge rather than on the edge of a nest (Spencer 2005). Additionally, unlike House Finches, Barn Swallows reuse the same nests many times, and the nest structures themselves can persist for years (Møller 1994). Here I present an observation of a House Finch occupying an abandoned Barn Swallow nest, an occurrence documented rarely.

I first observed a House Finch sitting inside a Barn Swallow nest on 18 July 2018 (Figure 1A). The nest was atop a light fixture under the roof edge of a building with a wooden exterior in Elkhorn Slough National Estuarine Reserve, California. The finch laid three eggs (Figure 1B), and all three hatched, the last on 26 July 2018, when I observed eggshell fragments around the third hatchling. Though there were Barn Swallows nearby while the House Finches used the nest, I noted no swallows harassing the House Finches. The finch treated the clay nest as platform, building a complete nest within it with outer layer, thick walls, and inside lining.

In a search online, I found only three similar observations of House Finches nesting in Barn Swallow nests - in Pennsylvania (www.hiltonpond.org/ThisWeek000415.html), South Carolina (www.marys-view.blogspot.com/2007/04/hit-and-miss.html), and

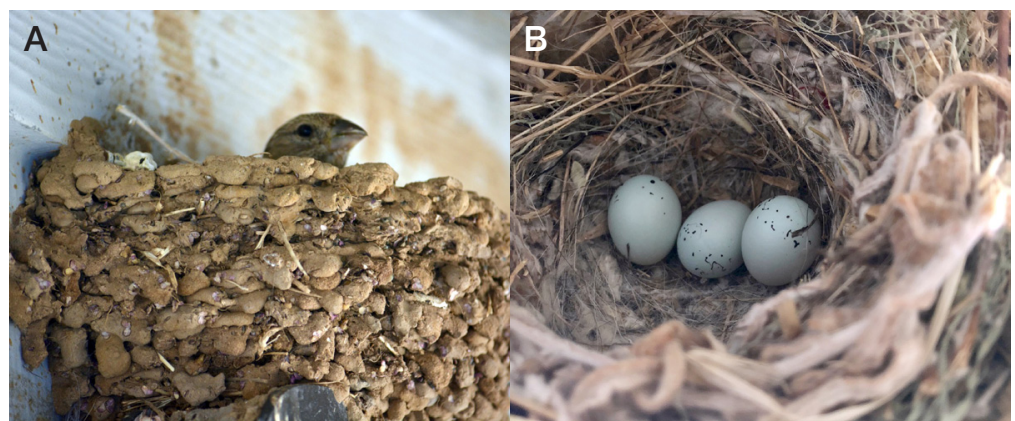

Figure 1. (A) House Finch incubating eggs in an abandoned Barn Swallow nest at Elkhorn Slough National Estuarine Reserve, California. (B) Clutch of House Finch eggs inside of nest. 


\section{NOTES}

North Carolina (www.nestwatch.org/connect/participant-photo/house-finch-eggs). Additionally, House Wrens (Troglodytes aedon) (Schafer 1916) and Eastern Phoebes (Sayornis phoebe) and Carolina Wrens (Thryothorus ludovicianus) (www.hiltonpond. org/ThisWeek000415.html) have also been observed using Barn Swallow nests. But given the House Finch's and Barn Swallow's now extensive overlap in habitat and range, the finch may use the swallow's nests more often than is currently understood. The species may compete, if the finch attempts to displace a swallow from an occupied nest rather than just adopting an abandoned nest.

Future research might examine the reasons why Barn Swallows abandon their nests, factors that cause other species to reuse them, and how the House Finch's nest placement is evolving as that species' range expands. Swallows may abandon nests heavily infested with parasites (Møller 1990), or nests may simply outlive their builders (Møller 1994). Reuse by other species could be driven by a breeding season extending beyond that of the Barn Swallow, or ability to displace Barn Swallows from their nest (Schafer 1916). As House Finches continue to expand their range, the types of structures they select for nests will also likely evolve, and continued use of Barn Swallow nests could link them even more closely with humans.

Thank you to J. P. Morton, B. R. Silliman, and J. Chan, along with reviewers A. V. Badyaev, D. D. Gibson, and P. Unitt for their helpful edits and comments. This work was supported by graduate research fellowship grant DGE-2017245336 from the National Science Foundation.

\section{LITERATURE CITED}

Aldrich, J. W., and Weske, J. S. 1978. Origin and evolution of the eastern House Finch population. Auk 95:528-536.

Alsop, F. J. 2006. Smithsonian Birds of North America. DK Publishing, New York.

Badyaev, A., Belloni, V., and Hill, G. 2012. House Finch (Haemorhous mexicanus), version 2, in The Birds of North America Online (A. Poole, ed.), no. 46. Cornell Lab Ornithol., Ithaca, NY; doi 10.2173/bna.46.

Evenden, F. G. 1957. Observations on nesting behavior of the House Finch. Condor 59:112-117; doi 10.2307/1364571.

Møller, A. P. 1990. Effects of parasitism by a haematophagous mite on reproduction in the Barn Swallow. Ecology 71:2345-2357; doi 10.2307/1938645.

Møller, A. P. 1994. Sexual selection and the Barn Swallow, in Model Systems in Behavioral Ecology: Integrating Conceptual, Theoretical, and Empirical Approaches (L. A. Dugatkin, ed.), pp. 359-380. Princeton Univ. Press, Princeton, NJ.

Schafer, J. 1916. Notes on the Barn Swallow. Wilson Bull. 28:88-90.

Spencer, K. 2005. The effects of body state on nest sanitation and provisioning effort in breeding Barn Swallows (Hirundo rustica). Can. J. Zool. 83:1360-1364; doi 10.1139/z05-122.

Accepted 16 May 2019 